\title{
Kepatuhan Diet Dan Aktivitas Fisik Pasien Diabetes Melitus Tipe 2 Yang Sudah Mengikuti Prolanis
}

\author{
Nida Herawati ${ }^{1}$, Mertien Sapang ${ }^{2}$, Harna $^{3}$ \\ 1,2,3Program Studi Gizi Fakultas Ilmu-Ilmu Kesehatan Universitas Esa Unggul, Jalan Arjuna Utara No. 9 Kebon Jeruk Jakarta 11510 \\ Korespondensi email: mertien.sapang@esaunggul.ac.id
}

Submitted: 31 Januari 2020, Revised: 20 Februari 2020, Accepted: 10 April 2020

\begin{abstract}
Indonesia ranks seventh most diabetes sufferers in the world. According to Riskesdas the prevalence of DM in Indonesia reached 2.0\% and in West Java Province reached 1.7\%. Promotive and preventive efforts developed by BPJS Kesehatan with primary health facilities are Prolanis for people with DM and bypertension so that patients and their families can monitor their health independently so that good and stable conditions are achieved. The purpose of this study was to determine the frequency distribution of diet adherence and physical activity of type 2 DM patients who had followed Prolanis. The method used is observational analytic, cross sectional design. The number of subjects was 50 respondents at the age of $\geq 45$ years. Data analysis looked at the frequency of characteristics, dietary adherence, and physical activity of type 2 DM patients who had followed Prolanis for at least 2 months. The results of this study stated that the average diet compliance score of 47.22 (cut-off mean > 41) meant that the respondent was compliant in carrying out dietary therapy. Average total physical activity 2808.76 METs bigh activity. The conclusion is the dietary obedience of respondents who followed Prolanis most obtained 47 categories of obedient respondents $(94.0 \%)$ in running DM diet therapy and 3 respondents $(6 \%)$ in not undergoing DM diet therapy. The most physical activity of respondents who took part in Prolanis was in the moderate activity category, 36 respondents (72.0\%) and the highest activity category was 14 respondents (28.0\%). Suggestions for respondents are expected to continue to be maintained regularly following Prolanis activities.
\end{abstract}

Keywords: Diabetes mellitus, prolanis, diet compliance, physical activity.

\section{Abstrak}

Indonesia menempati peringkat ke tujuh penderita diabetes terbanyak di dunia. Menurut Riskesdas prevalensi DM di Indonesia mencapai 2,0\% dan pada Provinsi Jawa Barat mencapai 1,7\%. Upaya promotif dan preventif yang dikembangkan BPJS Kesehatan dengan Fasilitas Kesehatan primer adalah Prolanis untuk penyandang DM dan hipertensi agar penderita dan keluarganya dapat mengawasi kesehatan diri secara mandiri sehingga tercapai keadaan yang baik dan stabil. Tujuan penelitian ini adalah mengetahui distribusi frekuensi kepatuhan diet dan aktivitas fisik pasien DM tipe 2 yang sudah mengikuti Prolanis. Metode yang digunakan analitik observasional, desain cross sectional. Jumlah subjek sebanyak 50 responden pada usia $\geq 45$ tahun. Analisis data melihat frekuensi karakteristik, kepatuhan diet, dan aktivitas fisik pasien DM tipe 2 yang sudah mengikuti Prolanis minimal 2 bulan. Hasil penelitian ini menyatakan bahwa rata-rata skor kepatuhan diet 47,22 (cut off mean $>41$ ) artinya responden patuh dalam menjalankan terapi diet. Rata-rata total aktivitas fisik 2808,76 METs aktivitas tinggi. Kesimpulan yaitu kepatuhan diet responden yang mengikuti Prolanis paling banyak didapatkan kategori patuh 47 responden (94,0\%) dalam menjalankan terapi diet DM dan tidak patuh 3 responden $(6 \%)$ dalam menjalankan terapi diet DM. Aktivitas fisik responden yang mengikuti Prolanis paling banyak didapatkan kategori aktivitas sedang yaitu 36 responden (72,0\%) dan didapatkan kategori aktivitas tinggi yaitu 14 responden (28,0\%). Saran bagi responden diharapkan untuk terus dijaga kerutinan mengikuti kegiatan Prolanis.

Kata kunci : Diabetes melitus, prolanis, kepatuhan diet, aktivitas fisik.

\section{Pendahuluan}

Diabetes Melitus (DM) adalah suatu keadaan dimana tubuh tidak bisa menghasilkan hormon insulin sesuai kebutuhan atau tubuh tidak bisa memanfaatkan secara optimal insulin yang dihasilkan, sehingga terjadi kelonjakan kadar gula dalam darah melebihi normal (1). Diabetes Melitus (DM) Tipe 2 merupakan jenis yang paling sering diderita oleh banyak orang. didapatkan. DM Tipe 2 biasanya timbul pada usia di atas 40 tahun, namun bisa pula timbul pada usia lebih muda atau sekitar 20 tahun. Sekitar $90-95 \%$ penderita diabetes adalah diabetes tipe 2 (2).

Menurut IDF tahun 2015, Indonesia menempati peringkat ke tujuh penderita diabetes terbanyak di dunia (3). Menurut Riskesdas tahun 2013, prevalensi diabetes melitus pada umur $\geq 15$ tahun di Indonesia sebesar 1,5\%, sedangkan Riskesdas pada tahun 2018 mencapai 2,0\% artinya prevalensi diabetes melitus di Indonesia terjadi kenaikan sebesar 0,5\%. Menurut Riset Kesehatan Dasar tahun 2013 prevalensi diabetes melitus berdasarkan diagnosis dokter pada penduduk umur $\geq 15$ tahun pada Provinsi Jawa Barat adalah 1,3\% (4). Menurut Riset Kesehatan Dasar tahun 2018 prevalensi diabetes melitus berdasarkan diagnosis dokter 
pada umur $\geq 15$ tahun pada Provinsi Jawa Barat adalah 1,7\% (5) yang artinya dari tahun 2013 sampai 2018 terjadi kenaikan sebesar 0,4\% prevalensi diabetes melitus di Jawa Barat. Di Kabupaten Karawang prevalensi pasien yang terdiagnosis diabetes sebesar 1,0\% dan dengan gejala sebesar 1,2\% (4).

Pengaturan diet yang baik merupakan kunci keberhasilan penatalaksanaan diabetes melitus (6). Pengaturan diet tersebut yaitu berdasarkan $3 \mathrm{~J}$, meliputi jumlah, jenis dan jadwal (7). Kepatuhan dalam diet merupakan salah satu faktor untuk menstabilkan kadar gula dalam darah menjadi normal dan mencegah komplikasi. Adapun faktor yang mempengaruhi seseorang tidak patuh terhadap diet diabetes melitus adalah kurangnya pengetahuan terhadap penyakit diabetes melitus, keyakinan, dan kepercayaan terhadap penyakit dibetes melitus (8). Ketidakpatuhan pasien dalam melakukan tatalaksana diabetes akan memberikan dampak negatif yang meliputi peningkatan biaya kesehatan dan komplikasi diabetes (9). Selain kepatuhan dalam menjalankan diet, pada diabetisi perlu diperhatikan aktivitas fisik dalam tiap harinya.

Aktivitas fisik merupakan gerakan yang dihasilkan oleh kontraksi otot rangka yang memerlukan energi melebihi pengeluaran energi selama istirahat (10). Aktivitas fisik merupakan salah satu empat pilar penatalaksanaan DM. Menurut Riset Kesehatan Dasar tahun 2018 proporsi aktivitas fisik pada penduduk umur $\geq 10$ tahun di Indonesia sebesar 66,5\% kategori cukup dan 33,5\% kategori kurang. Proporsi aktivitas fisik pada penduduk umur $\geq 10$ tahun di Jawa Barat sendiri sebesar 62,5\% kategori cukup dan 37,5\% kategori kurang (5). Penelitian yang dilakukan oleh Nurayati dan Adriani pada tahun 2017 tentang hubungan aktivitas fisik dengan kadar gula darah puasa penderita diabetes melitus tipe 2 menyatakan bahwa data sebanyak 62,9\% responden memiliki aktivitas fisik rendah dan sebanyak 58,0\% responden memiliki kadar gula darah puasa dalam kategori tinggi (11). Aktivitas fisik yang kurang juga merupakan salah satu penyebab meningkatnya angka kejadian diabetes melitus (12). Diabetes melitus merupakan salah satu penyakit kronis.

Penyakit kronis yang dialami oleh masyarakat dewasa ini akan memberikan dampak dan beban bagi keluarga, bila penanganan dilakukan secara tidak intensif dan berkelanjutan. Manfaat penanganan yang intensif bagi penderita adalah dapat mengenal tanda bahaya dan tindakan segera bila mengalami kegawatdaruratan. Berlakunya Jaminan Kesehatan Nasional sejak Januari 2014, sesuai amanah Undang-Undang No. 40 Tahun 2004 tentang Sistem Jaminan Sosial Nasional dan Undang-Undang No. 24 Tahun 2011 tentang BPJS, maka Fasilitas Kesehatan Tingkat Pertama (Puskesmas) sebagai garda terdepan dalam memberikan pelayanan kepada masyarakat dapat melaksanakan PROLANIS, melalui kerjasama dengan BPJS untuk melakukan pembinaan bagi penderita kronis (13).

Program Pengelolaan Penyakit Kronis (PROLANIS) adalah suatu sistem pelayanan kesehatan dan pendekatan proaktif yang dilaksanakan secara terintegrasi yang melibatkan Peserta, Fasilitas Kesehatan dan BPJS Kesehatan dalam rangka pemeliharaan kesehatan bagi peserta BPJS Kesehatan yang menderita penyakit kronis. Tujuannya untuk mendorong peserta penyandang penyakit kronis mencapai kualitas hidup optimal dengan indikator $75 \%$ peserta terdaftar yang berkunjung ke Faskes Tingkat Pertama memiliki hasil "baik" pada pemeriksaan spesifik terhadap penyakit DM Tipe 2 dan Hipertensi sesuai panduan klinis terkait sehingga dapat mencegah timbulnya komplikasi penyakit (14).

Sasarannya adalah peserta BPJS Kesehatan penyandang penyakit DM Tipe 2 dan Hipertensi. Kegiatan rutin yang dilaksanakan yaitu pemeriksaan status kesehatan, penyuluhan atau edukasi, senam bersama, dan pemberian obat (13). Menurut hasil Kapitasi Berbasis Kinerja (KBK) Puskesmas Bulan Pelayanan April-Juni 2018 di Karawang rata-rata tertinggi yang aktif melaksanakan PROLANIS dilakukan di Puskesmas Nagasari yaitu sebesar 97,98\% dan hasil rata-rata terendah di Puskesmas Medangasem yaitu sebesar 1,39\% dan Puskesmas Sukatani yaitu sebesar $0,68 \%$ (14). Puskesmas adalah salah satu sarana pelayanan kesehatan yang menjadi andalan atau tolak ukur dari pembangunan kesehatan, saranan peran serta masyarakat, dan pusat pelayanan pertama yang menyeluruh dari suatu wilayah (15). Puskesmas bekerja sama dengan BPJS Kesehatan untuk memberikan kontribusi dan distribusi terhadap masyarakat dalam pelayanan kesehatan secara menyeluruh terutama pada kasus penyakit diabetes melitus tipe 2 dengan adanya Program Pengelolaan Penyakit Kronis (PROLANIS).

Dengan adanya kegiatan Prolanis ini, peneliti tertarik menginvestigasi kepatuhan diet dan aktivitas fisik pada penderita diabetes melitus tipe 2 yang sudah mengikuti Prolanis. Tujuan dari penelitian ini yaitu untuk mengetahui distribusi frekuensi karakteristik, kepatuhan diet, dan aktivitas fisik pasien diabetes melitus tipe 2 yang sudah mengikuti Prolanis.

\section{Metode Penelitian}

Jenis penelitian yang digunakan adalah analitik observasional dengan desain penelitian study cross sectional. Lokasi di Puskesmas Nagasari Kabupaten Karawang yang merupakan puskesmas aktif dalam melaksanakan kegiatan Prolanis. Waktu penelitian dilakukan pada pertengahan bulan Juni 2019, karena kegiatan Prolanis tersebut biasa dilaksanakan pada pertengahan bulan. Populasi dalam penelitian ini adalah penderita dengan 
diagnosa diabetes melitus tipe 2. Berdasarkan perhitungan subjek didapatkan 50 responden. Penelitian ini menggunakan teknik non-probabilitas dengan cara purposive sampling yaitu teknik penetapan subjek dengan cara memilih subjek populasi sesuai yang dikehendaki sehingga subjek tersebut mewakili karakteristik populasi yang telah dikenal sebelumnya.

Kriteria inklusi pada penelitian ini adalah laki-laki dan perempuan usia $\geq 45$ tahun, penderita dengan diagnosa Diabetes Melitus Tipe 2, tidak menderita cacat fisik, gangguan mental, dan demensia, peserta yang bersedia mengikuti penelitian dengan mendatangani informed concent. Kriteria eksklusi pada penelitian ini adalah penderita Diabetes Melitus dengan komplikasi.

Jenis data yang digunakan yaitu data primer dan sekunder. Data primer terdiri dari nama, jenis kelamin, umur, pendidikan terakhir, pekerjaan, penghasilan, lama menderita diabetes melitus. Selain itu, data primer yaitu data kepatuhan diet dan aktivitas fisik responden saat kegiatan turun lapang berlangsung menggunakan kuesioner yang sudah terstandar berupa kuesioner kepatuhan diet yang sudah diuji validitas dan reliabilitas yang dilakukan pada penelitian Enfriyanurika tahun 2018 (16). Rata-rata skor kepatuhan diet yang didapatkan pada penelitian ini yaitu 41, maka responden yang dikatakan patuh menjalankan terapi diet apabila nilai skor kepatuhan diet didapatkan $>41$ dan tidak patuh dibawah $\leq 41$. Aktivitas fisik menggunakan kuesioner IPAQ-SF dengan cara wawancara. Sementara itu, untuk data sekunder berasal dari data prevalensi penderita diabetes melitus di Karawang, daftar penderita diabetes melitus di Puskesmas Kabupaten Karawang, penderita diabetes melitus di Puskesmas Nagasari, data rata-rata angka keikutsertaan PROLANIS di Puskesmas Kabupaten Karawang. Penelitian ini telah lolos Kaji Etik oleh Komite Etik Universitas Esa Unggul. Berdasarkan surat etik nomor : 0135-19.120/DPKE-KEP/FINAL-EA/ UEU/V/2019 pada tanggal 27 Mei 2019 penelitian ini layak etik dengan memenuhi aspek lembar persetujuan (Informed Concent) dan peneliti menjamin kerahasiaan responden.

\section{Hasil dan Pembahasan}

\section{Karakteristik Subjek}

Tabel 1. menunjukkan bahwa karakteristik responden di Puskesmas Nagasari meliputi sebagian besar jenis kelamin yang paling banyak perempuan yaitu 35 responden. Umur paling banyak pada kelompok 45-59 tahun yaitu 34 responden. Pendidikan terakhir responden paling banyak lulus SD yaitu 17 responden. Pekerjaan lebih banyak pegawai swasta yaitu 18 responden. Penghasilan Upah Minimum Kabupaten Karawang paling banyak didapatkan $\leq$ Rp.4.200.000 yaitu 27 responden. Lama menderita diabetes melitus yang paling banyak $\leq 5$ tahun yaitu 27 responden.

Tabel 1.

Karakteristik Pasien Diabetes Melitus Tipe 2 yang Sudah Mengikuti Prolanis

\begin{tabular}{lc}
\hline \multicolumn{1}{c}{ Variabel } & $\mathbf{n}\left(\mathbf{( \% )} \mathbf{1}^{\mathbf{1}}\right.$ \\
\hline Jenis Kelamin & $15(30.0)$ \\
Laki-laki & $35(70.0)$ \\
Perempuan & $34(68.0)$ \\
Umur & $12(24.0)$ \\
$45-59$ tahun & $4(8.0)$ \\
60-69 tahun & $17(34.0)$ \\
$>70$ tahun & $16(32.0)$ \\
Pendidikan Terakhir & $9(18.0)$ \\
Lulus SD/Sederajat & $8(16.0)$ \\
Lulus SMP & $18(36.0)$ \\
Lulus SMA & $17(34.0)$ \\
Lulus Perguruan Tinggi (DIII/DIV/S1/S2/S3) & $9(18.0)$ \\
Pekerjaan & $6(12.0)$ \\
Pegawai Swasta & \\
Pegawai Negeri Sipil & $27(54.0)$ \\
Wiraswasta & $23(46.0)$ \\
Petani/Nelayan/Buruh & \\
Penghasilan ${ }^{2}$ & $27(54.0)$ \\
$\leq$ Rp. 4.200.000 & $23(46.0)$ \\
> Rp. 4.200.000 &
\end{tabular}


Berdasarkan data yang diperoleh jenis kelamin perempuan lebih banyak terkena penyakit diabetes melitus melitus tipe 2. Jenis kelamin tidak termasuk dalam faktor yang menyebabkan seseorang terkena DM. Penyebab banyaknya angka kejadian DM terjadi pada perempuan dikarenakan perempuan terjadi penurunan hormon estrogen akibat menopause. Hormon estrogen dan progesteron merupakan hormon yang dapat mempengaruhi sel-sel untuk merespon insulin. Setelah perempuan mengalami menopause maka akan terjadi perubahan kadar hormon tersebut sehingga dapat memicu naik turunnya kadar gula dalam darah (17). Peningkatan risiko diabetes seiring dengan umur, khususnya pada umur lebih 40 tahun, disebabkan karena pada usia tersebut mulai terjadi peningkatan intoleransi glukosa. Adanya proses penuaan menyebabkan berkurangnya kemampuan sel $\beta$ pancreas dalam meproduksi insulin (18). Selain itu pada individu yang berusia lebih tua terdapat penurunan aktivitas mitokondria di sel-sel otot sebesar 35\%. Hal ini berhubungan dengan peningkatan kadar lemak di otot sebesar 30\% dan memicu terjadinya resisten insulin (19).

Pendidikan terakhir responden di Puskesmas Nagasari didapatkan yaitu lulus SD sebanyak 17 orang, lulus SMP sebanyak 16 orang, lulus SMA sebanyak 9 orang, dan lulus Perguruan Tinggi (DIII/DIV/S1/S2/S3) sebanyak 8 orang. Tingkat pendidikan memiliki pengaruh terhadap kejadian penyakit DM Tipe 2. Orang yang tingkat pendidikannya tinggi biasanya akan memiliki banyak pengetahuan tentang kesehatan. Dengan adanya pengetahuan tersebut seseorang akan memiliki kesadaran dalam menjaga kesehatannya (20).

\section{Kepatuhan Diet Pasien DM Tipe 2 Prolanis}

Kepatuhan diet adalah suatu perilaku pasien dalam melaksanakan pemenuhan asupan makanan yang telah direkomendasikan oleh penyedia pelayanan kesehatan (21). Pengaturan diet tersebut yaitu berdasarkan $3 \mathrm{~J}$, meliputi jumlah, jenis dan jadwal (7). Interaksi diet mempengaruhi pola makan lemak tubuh yang memiliki peranan yang signifikan dalam menentukan sensitivitas insulin. Modifikasi diet dapat dilakukan dengan menghindari asupan kalori yang berlebihan dan diet tinggi lemak dengan mengonsumsi karbohidrat kompleks, buah, dan sayur-sayuran (22).

Tabel 2.

Kategori Kepatuhan Diet Pasien Diabetes Melitus Tipe 2 yang Sudah Mengikuti Prolanis

\begin{tabular}{|c|c|c|}
\hline \multirow{2}{*}{ Kepatuhan Diet } & \multicolumn{2}{|c|}{ Jumlah } \\
\hline & $\mathrm{n}^{1}$ & $\% 0^{2}$ \\
\hline Patuh (cut off mean $>41)^{3}$ & 47 & 94.0 \\
\hline Tidak Patuh (cut off mean $\leq 41)^{4}$ & 3 & 6.0 \\
\hline Total & 50 & 100 \\
\hline
\end{tabular}

Tabel 2. menunjukkan bahwa kepatuhan diet responden yang mengikuti Prolanis paling banyak didapatkan kategori patuh dalam menjalankan terapi diet DM yaitu 47 responden $(94,0 \%)$ dan didapatkan kategori tidak patuh terapi diet DM yaitu 3 responden $(6 \%)$. Patuh dalam menjalankan diet apabila cut off mean $>41$ dan tidak patuh dalam menjalankan diet apabila cut off mean $\leq 41$.

Diet diabetes melitus merupakan pengaturan pola makan bagi Diabetesi berdasarkan jumlah, jenis, dan jadwal pemberian makanan. Tujuan dari kepatuhan diet adalah untuk mencapai dan mempertahankan lipid mendekati normal, mencapai berat badan normal, menghindari atau menangani komplikasi akut pasien yang menggunakan insulin seperti hipoglikemia, komplikasi jangka pendek, komplikasi jangka lama serta masalah yang berhubungan dengan latihan jasmani, dan meningkatkan kualitas hidup sehingga dapat melakukan pekerjaan sehari-hari, membiasakan diri untuk makan tepat waktu agar tidak terjadi perubahan kadar glukosa darah, dan meningkatkan derajat kesehatan secara komprehensif melalui gizi yang optimal (23).

Responden yang tidak patuh melakukan diet kemungkinan mempunyai kadar gula darah tinggi lebih besar dibandingkan dengan responden yang patuh melakukan diet. Ketidakpatuhan diet ditunjukkan dengan perilaku responden dalam mengonsumsi makanan tanpa memilih jenis-jenis makanan yang bermanfaat seperti makanan yang tinggi serat yaitu hidangan sayur. Perilaku ketidakpatuhan responden terhadap diet diabetes melitus dapat disebabkan karena ketidaktauan responden tentang diet diabetes misalnya batasan-batasan dalam mengonsumsi gula, garam, dan minyak. Responden yang tidak mengetahui tentang diet DM akan mengonsumsi makanan sesuai seleranya tanpa memperhitungkan manfaat makanan bagi kesehatan yang dikonsumsinya (24).

Responden yang mengikuti Prolanis (Puskesmas Nagasari) pada nilai rata-rata skor didapatkan 47,22 (cut off mean $>41$ ) artinya patuh dalam menjalankan terapi diet. Kepatuhan adalah tingkat pasien dalam melaksanakan 
cara pengobatan dan perilaku yang disarankan oleh dokter atau paramedis. Hal tersebut, dikarenakan didalam Prolanis diberikan intervensi edukasi tentang kesehatan dan gizi. Pemberian Edukasi Prolanis dinamakan Edukasi Risti (Klub Prolanis) yang merupakan kegiatan untuk meningkatkan pengetahuan dan sikap kesehatan dalam upaya memulihkan penyakit dan mencegah timbulnya kembali penyakit serta meningkatkan status kesehatan bagi peserta Prolanis. Selain kegiatan pemberian edukasi, peserta rutin dilakukan konsultasi medis dengan jadwal konsultasi disepakati bersama antar peserta dengan Faskes Pengelola (13). Sehingga, dari pemberian edukasi dan konseling rutin tersebut diharapkan dapat membuat peserta Prolanis lebih sadar akan pola makan dan kesehatannya. Kegiatan tersebut yang dilakukan satu kali dalam sebulan. Kegiatan penyuluhan dilakukan oleh Ahli Gizi, Dokter, dan Bidan secara bergantian.

Penelitian ini menunjukkan bahwa sebagian besar responden patuh dalam menjalankan terapi diet yaitu patuh sebesar $47(94,0 \%)$ dan didapatkan kategori tidak patuh terapi diet DM yaitu $3(6 \%)$. Penelitian ini sejalan dengan penelitian yang dilakukan oleh Pujiastuti Tahun 2016 menyatakan bahwa proporsi responden kepatuhan pasien DM Tipe II melaksanakan diet DM Tipe II, dari 240 responden terdapat 128 responden (53\%) yang patuh dan 112 responden (47\%) tidak patuh menjalani diet DM Tipe II (25). Penelitian yang dilakukan oleh Yulia Tahun 2015 distribusi responden berdasarkan kepatuhan dalam menjalankan diet yaitu tidak patuh sebanyak 48 responden (68,6\%) dan yang patuh sebanyak 22 responden (31,4\%) (26).

Hasil analisis penelitian ini dengan adanya penyuluhan dan konsultasi kesehatan dan gizi tersebut responden yang mengikuti Prolanis dapat patuh dalam menjalankan diet. Tujuan penyuluhan gizi bagi penderita DM adalah untuk meningkatkan pengetahuan yang akan menjadi titik tolak perubahan sikap dan gaya hidup seseorang sehingga akan mencapai kualitas hidup yang lebih baik, oleh karena itu semakin sering seseorang mendapatkan penyuluhan maka akan semakin baik pula perilakunya (27).

Konsultasi gizi adalah salah satu intervensi yang menekankan pada pemberian informasi dan pendidikan gizi terkait dengan masalah gizi yang dialami oleh individu. Konsultasi gizi dapat berperan dalam mengubah perilaku terkait konsumsi makanan berisiko tersebut dan menurunkan angka prevalensi penyakit degeneratif [28]. Hal ini sejalan dengan penelitian yang menyatakan bahwa ada hubungan pemberian frekuensi konsultasi gizi dengan kepatuhan diet penderita diabetes melitus tipe 2 (29).

\section{Aktivitas Fisik Pasien DM Tipe 2 Prolanis}

Aktivitas fisik adalah gerakan anggota tubuh yang diproduksi oleh kontraksi otot sehingga menghasilkan tenaga yang berfungsi untuk pemeliharaan kesehatan fisik dan mental serta mempertahankan kualitas hidup agar tetap sehat dan bugar setiap hari (30). Pada penderita DM tipe 2 untuk mengatur kadar glukosa darah adalah dengan melakukan latihan jasmani yaitu senam diabetes melitus (31).

Tabel 3. menunjukkan bahwa aktivitas fisik responden yang mengikuti Prolanis paling banyak didapatkan kategori aktivitas sedang yaitu 36 responden (72,0\%) dan didapatkan kategori aktivitas tinggi yaitu 14 responden $(28,0 \%)$. Penelitian ini pasien DM yang sudah mengikuti Prolanis didapatkan nilai rata-rata aktivitas fisik dalam skor kategori IPAQ-SF tinggi. Aktivitas tinggi yaitu aktivitas intensitas tinggi setidaknya 3 hari dengan total minimal 1500 MET-menit/minggu atau aktivitas intensitas sedang atau tinggi dengan total minimal 3000 METmenit/minggu. Namun, nilai rata-rata skor aktivitas fisik yang mengikuti Prolanis cenderung lebih baik daripada responden yang tidak mengikuti Prolanis.

Tabel 3.

Kategori Aktivitas Fisik Pasien Diabetes Melitus Tipe 2 yang Sudah Mengikuti Prolanis

\begin{tabular}{|c|c|c|}
\hline \multirow{2}{*}{ Aktivitas Fisik } & \multicolumn{2}{|c|}{ Jumlah } \\
\hline & $\mathbf{n}^{1}$ & $\% 0^{2}$ \\
\hline Sedang (MET-menit/minggu) ${ }^{3}$ & 36 & 72.0 \\
\hline Tinggi (MET-menit/minggu) ${ }^{4}$ & 14 & 28.0 \\
\hline Total & 50 & 100 \\
\hline
\end{tabular}

Kegiatan dalam Prolanis salah satunya adalah melakukan latihan jasmani yaitu senam. Senam diabetes melitus dapat menyebabkan terjadinya peningkatan pemakaian glukosa oleh otot yang aktif, sehingga secara langsung senam diabetes melitus menyebabkan penurunan kadar glukosa (32). Latihan jasmani merupakan upaya awal dalam mencegah, mengontrol, dan mengatasi diabetes melitus. Latihan jasmani menyebabkan terjadinya peningkatan aliran darah, jala-jala kapiler lebih banyak terbuka sehingga lebih banyak terbuka sehingga lebih 
banyak tersedia reseptor insulin dan reseptor menjadi lebih aktif yang akan mempengaruhi terhadap penurunan glukosa darah pada pasien diabetes melitus (32).

Kegiatan senam bersama telah dilakukan rutin disetiap kegiatan Prolanis untuk meningkatkan kebugaran jasmani peserta, hal tersebut sesuai dengan anjuran pemerintah yang bekerjasama dengan BPJS Kesehatan untuk mendukung. Realisasi kegiatan senam ini tidak terlepas dari dukungan dan kesadaran keluarga sehingga para peserta merasa termotivasi untuk melakukan senam bersama demi kualitas kesehatannya dan menjalani harinya dengan sehat dan bahagia. Latihan jasmani yang dianjurkan adalah latihan secara teratur (3-4 kali seminggu selama kurang lebih 30 menit.), kemudian tetap melakukan kegiatan sehari-hari seperti berjalan ke pasar, dan lain sebagainya. Aktivitas fisik secara teratur dapat menurunkan berat badan, mengurangi resistensi insulin yang pada akhrinya mampu mengontrol gula darah (33).

Perhimpunan Endokrinolog Indoenesia (Perkeni) menganjurkan penderita DM untuk mengurangi aktivitas sedenter (menonton televisi, menggunaakan internet, main game computer), mempersering aktivitas seperti berolahraga, rekreasi, dan aktivitas yang tinggi ketika liburan (jalan cepat, golf, olah otot, bersepeda, sepak bola), serta menganjurkan untuk membiasakan bergaya hidup sehat seperti berjalan kaki ke pasar tanpa menggunakan kendaraan, menggunakan tangga bukan lift, dan sebagainya) (7). Penelitian ini sejalan dengan penelitian Akmal Tahun 2012 yang menyatakan bahwa terdapat perbedaan bermakna aktivitas fisik antara lansia yang mengikuti dan tidak mengikuti senam bugar lansia di Instalasi Geriatri Paviliun Lanjut Usia Prof. Boedhi Darmojo RSUP Dr. Kariadi Semarang. Oleh karena itu senam dapat menambah aktivitas fisik pada lansia (34).

\section{Kesimpulan}

Skor kepatuhan diet responden yang mengikuti Prolanis paling banyak didapatkan kategori patuh dalam menjalankan terapi diet DM yaitu 47 responden $(94,0 \%)$ dan didapatkan kategori tidak patuh terapi diet DM yaitu 3 responden (6\%). Aktivitas fisik responden yang mengikuti Prolanis paling banyak didapatkan kategori aktivitas sedang yaitu 36 responden $(72,0 \%)$ dan didapatkan kategori aktivitas tinggi yaitu 14 responden $(28,0 \%)$. Adanya kegiatan Prolanis di Puskesmas kepatuhan diet dan aktivitas fisik pada pasien Diabetes Melitus Tipe 2 sudah baik, sehingga saran untuk kedepannya kegiatan Prolanis agar tetap dipertahankan, sedangkan bagi Puskesmas dan pasien yang belum melaksanakan kegiatan Prolanis diharapkan kedepannya untuk mulai aktif.

\section{Daftar Pustaka}

1 Ig. M. G. J. H. E. Haryati, "Hubungan Faktor Risiko Umur, Jenis Kelamin, Kegemukan dan Hipertensi dengan Kejadian Diabetes Melitus Tipe II di Wilayah Werja Puskesmas Mataram.,” Media Bina Ilmiah39, vol. 8, no. 1978, pp. 39-44, 2014.

2 H. Tandra, Diabetes Bisa Sembub Petunjuk Praktis Mengalabkan dan Menyembubkan Diabetes. Jakarta: Gramedia Pustaka Utama, 2016.

3 IDF, “International Diabetes Federation 2015,” IDF Diabetes Atlas Sixth Edition, 2015. .

4 Kemenkes RI, RISET KESEHATAN DASAR 2013. Jakarta: Kemenkes RI, 2013.

5 Kemenkes RI, Riset Kesehatan Dasar 2018. Kemenkes RI, 2018.

6 M. Ghoffar, Salat Olahraga Ampuh untuk Diabetes Melitus. Jakarta: Graha Ilmu, 2012.

7 PERKENI, Konsensus Pengelolaan dan Pencegahan Diabetes Tipe 2 di Indonesia 2015. Jakarta: PERKENI, 2015.

8 P. I. Dwipayanti, "Hubungan Pengetahuan tentang Diet Diabetes Mellitus Dengan Kepatuhan Pelaksanaan Diet pada Penderita Diabetes Mellitus," J. Keperawatan Kebidanan - Stikes Dian Husada Mojokerto, vol. 1, no. 1, pp. 47-53, 2011.

9 A. Y. Nur Aini, Widati Fatmaningrum, "Diabetes Mellitus dengan Pendekatan Teori Model Behavioral System Dorothy E . Johnson (Changing the Patient's Behavior in Diabetes Mellitus Management by Application Dorothy E. Johnson's Behavioral System Model )," J. Ners, vol. 6, no. 1, pp. 1-10, 2011.

10 D. Astuti and S. K. Husada, Pengaruh Senam Aerobik Terbadap Kadar Gula Darah Puasa Penderita Diabetes MelitusTipe 2 pada Kelompok Prolanis UPT Puskesmas Wonogiri 1. Surakarta: STIKES Kusuma Husada, 2016.

11 L. Nurayati and M. Adriani, "Hubungan Aktifitas Fisik dengan Kadar Gula Darah Puasa Penderita Diabetes Melitus Tipe 2 Association Between Physical Activity and Fasting Blood Glucose Among Type 2 Diabetes Mellitus patients," Amerta Nutr., vol. 1, no. 1, pp. 80-87, 2017.

12 M. Azitha, D. Aprilia, and Y. R. Ilhami, "Hubungan Aktivitas Fisik dengan Kadar Glukosa Darah Puasa pada Pasien Diabetes Melitus yang Datang ke Poli Klinik Penyakit Dalam Rumah Sakit M . Djamil Padang,” J. Fak. UNAND, vol. 7, no. 3, pp. 400-404, 2018.

13 BPJS Kesehatan, Panduan Praktis PROLANIS (Program Pengelolaan PROLANIS Program Pengelolaan Penyakit Kronis. BPJS Kesehatan, 2014.

14 BPJS Kesehatan, Monitoring dan Evaluasi Kapitasi Berbasis Komitmen Puskesmas Kabupaten Karawang Bulan Pelayanan AprilJuni 2018. BPJS Kesehatan, 2018.

15 Alamsyah and Muliawati, Pilar Dasar Kesehatan Masyarakat. Yogyakarta: Nuha Medika, 2013.

16 L. Enfriyanurika, "Kuesioner Kepatuhan Diet," Jakarta, 2018. 
17 D. T. Utami, D. Karim, P. Studi, I. Keperawatan, and U. Riau, "Diabetes Mellitus dengan Ulkus Diabetikum," JOM PSIK, vol. 1, no. 2, pp. 1-7, 2012.

18 Sujayana and I. Nyoman, "No Title," J. Skala Husada, vol. 1, no. 1, pp. 75-81, 2009.

19 S. K. Trisnawati and S. Setyorogo, "Faktor Risiko Kejadian Diabetes Melitus Tipe II Di Puskesmas Kecamatan Cengkareng Jakarta Barat Tahun 2012,” J. Ilm. Kesehat., vol. 5, no. 1, pp. 6-11, 2013.

20 Irawan, "Prevalensi dan Faktor Risiko Kejadian Diabetes Melitus Tipe 2 di Daerah Urban Indonesia (Analisis Data Sekunder Riskesdas 2007)," Universitas Indonesia.

21 D. D. Dunlop, S. L. Hughes, and L. M. Manheim, "Daily -Living: Hierarchy Activities of Daily Living :," Am. J. Public Health, vol. 1, no. 3, p. 87, 2012.

22 Ramachandran, "Temporal changes in prevalence of diabetes and impaired glucose tolerance associated with lifestyle transition occurring in the rural population in India," Diabetologia, vol. 1, no. 1, pp. 860-865, 2009.

23 Sulistyowati, Diabetes Melitus di Indonesia dan Ilmu Penyakit Dalam Edisi 5. Jakarta: Interna Publishing, 2011.

24 R. Hardianzah, "Hubungan Aktivitas Fisik dan Kepatuhan Diet dengan Kadar Gula Darah pada Penderita Diabetes Melitus di Wilayah Kerja Puskesmas Bantul I Yogyakarta,” STIKES 'Aisyiyah vol. 2, no. 5, p. 255, 2009.

25 E. Pujiastuti, "Hubungan pengetahuan dan motivasi dengan kepatuhan diet pada pasien diabetes mellitus tipe ii di poliklinik penyakit dalam rsud dr. soehadi prijonegoro sragen," STIKES Kusuma Husada, 2016.

26 S. Yulia, "Kepatuhan dalam Menjalankan Diet pada Penderita Diabetes Mellitus Tipe 2," Universitas Negeri Semarang, 2015.

27 Lestari, "Hubungan Psikososial dan Penyuluhan Gizi dengan Kepatuhan Diet Pasien Diabetes Mellitus Tipe 2 Rawat Jalan di RSUP Fatmawati Tahun 2012," Universitas Indonesia, 2012.

28 W. R. Handarbeny and T. Mahmudiono, "Pengaruh Pendidikan Gizi Berbasis Theory of Planned Behavior untuk Mempromosikan Pembatasan Konsumsi Fast Food pada Siswi The Effectiveness of Nutrition Education Based on Theory of Planned Behavior to Promote Limited Fast Food Consumption in Girl Student," Amerta Nutr., vol. 1, no. 1, pp. 351-360, 2017.

29 E. Mona, S. Bintanah, and R. Astuti, "Hubungan Frekuensi Pemberian Konsultasi Gizi dengan Kepatuhan Diit Serta Kadar Gula Darah Penderita Diabetes Mellitus Tipe II Rawat Jalan di RS Tugurejo Semarang," Junal Gizi Univ. Muhammadiyah Semarang, vol. 1, no. November, pp. 1-9, 2012.

30 Fatmah, Giri Usia Lanjut. Jakarta: Erlangga.

31 A. Salindeho, Mulyadi, and J. Rottie, "Pengaruh Senam Diabetes Melitus Terhadap Kadar Gula Darah Penderita Diabetes Melitus Tipe 2 di Sanggar Senam Persadia Kabupaten Gorontalo,” ejournal Keperawatan (eKp), vol. 4, no. 1, pp. 1-7, 2016.

32 Sogondo, Soewondo, and Subekti, No Title. Jakarta: FKUI, 2009.

33 A. Z. Muttaqin and F. B. R, "Hubungan dukungan keluarga dengan tingkat kepatuhan lanjut usia dalam melaksanakan senam lansia di posyandu kondang waras desa ngargorejo boyolali," Keperawatan UMS, vol. 1, no. 1, pp. 11-18, 2020.

34 H. F. Akmal, "Perbedaan asupan energi, protein, aktivitas fisik dan status gizi antara lansia yang mengikuti dan tidak mengikuti senam bugar lansia," Universitas Dipenogoro, 2012. 